\title{
Faktor Prioritas Penyebab Kumuh Kawasan Permukiman Kumuh Di Kelurahan Belitung Selatan, Kota Banjarmasin
}

\author{
Abi Syarwan Wimardana, dan Rulli Pratiwi Setiawan \\ Jurusan Perencanaan Wilayah dan Kota, Fakultas Teknik Sipil dan Perencanaan \\ Institut Teknologi Sepuluh Nopember (ITS) \\ Jl. Arief Rahman Hakim, Surabaya 60111 Indonesia \\ e-mail:rulli.setiawan@urplan.its.ac.id
}

\begin{abstract}
Abstrak - Kenaikan laju pertumbuhan penduduk memiliki dampak pada tingginya akses terhadap kebutuhan-kebutuhan primer salah satunya adalah kebutuhan akan rumah tinggal. Hal tersebut merupakan salah satu pemicu munculnya permukiman kumuh. Keberadaan permukiman kumuh di Kota Banjarmasin mengindikasikan munculnya permasalahan sosial dan lingkungan yang besar, salah satunya terjadi di wilayah Kelurahan Belitung Selatan. Permukiman kumuh tersebar di 10 RT Kelurahan Belitung Selatan. Yang termasuk dalam kategori kumuh ringan terdapat 9 Rukun Tangga (RT 4,8,9,10,11,12,13,14,15) dan Kumuh Ringan 1 Rukun Tangga (RT 6). Karakteristik permukiman kumuh di Kelurahan Belitung Selatan memiliki tingkat kepadatan bangunan yang cukup tinggi dan rata-rata luas persil kecil, serta kondisi bangunan yang cukup tua. Luas permukiman kumuh pada 10 RT sebesar 6,04 Ha. Kawasan kumuh terdiri dari rumah 480 Unit dengan persebaran jumlah penduduk 1.920 jiwa pada kawasan permukiman kumuh Kelurahan Belitung Selatan. Penelitian ini bertujuan menentukan faktor prioritas penyebab kumuh, dengan melakukan pencapaian tahapan sasaran yaitu mengidentifikasi karakteristik kawasan permukiman kumuh, serta menganalisis dalam menentukan faktor prioritas penyebab kumuh permukiman kumuh di Kelurahan Belitung Selatan. Dalam mencapai tujuan tersebut maka dilakukan beberapa tahapan analisis. Pertama, mengidentifikasi karakteristik permukiman kumuh di Kelurahan Belitung Selatan melalui analisis statistik deskriptif. Tahap selanjutnya yaitu menganalisis faktor prioritas yang mempengaruhi permukiman kumuh melalui analisa stakeholder dan menggunakan teknik analisis AHP (Analythical Hierarchy Process) dalam penentuan faktor prioritas penyebab kumuh serta turunan faktor berupa variabel penyebab kumuh.
\end{abstract}

Kata Kunci-Permukiman kumuh, Karakteristik, Faktor penyebab kumuh, Prioritas.

\section{PENDAHULUAN}

$\mathrm{U}$ RBANISASI di Indonesia saat ini berlangsung demikian pesat. Persoalan urbanisasi, kemiskinan dan lingkungan adalah tiga hal yang berkait [1]. Para ahli perencanaan kota memproyeksikan jumlah penduduk di wilayah urban di dunia akan mencapai 50-60\% dari jumlah penduduk antara tahun 2020-2025 [2]. Dalam sepuluh tahun terakhir jumlah penduduk perkotaan berkembang dari $48 \%$ menjadi $56 \%$ dari keseluruhan jumlah penduduk [3]. Proses ini akan terus berjalan ketika masih ada faktor pendorong (kehidupan yang sulit di perdesaan/kota kecil) maupun faktor penarik yaitu, kehidupan yang lebih baik di perkotaan [4].
Menurut data identifikasi yang dilaksanakan Kementerian Pekerjaan Umum dan Perumahan Rakyat pada tahun 2015 terdapat 38.431 ha permukiman kumuh pada 4.108 kawasan di seluruh Indonesia yang menjadi target penataan dan perbaikan hingga tuntas (nol persen), sampai tahun 2019 [5]. Salah satu permukiman kumuh tersebut terletak di Kota Banjarmasin [6]. Masalah lingkungan perkotaan Kota Banjarmasin disebabkan oleh karakteristik lahan basah atau gambut yang terdapat pada kawasan lahan perkotaan di Kota Banjarmasin memiliki permasalahan lingkungan dan kebencanaan [7]. Sebagai contoh, tidak jarang ditemukan adanya bangunan baik itu bangunan bertingkat atau permukiman yang mengalami kondisi miring bahkan runtuh akibat terjadinya penurunan muka tanah serta penyebaran api akibat bencana kebakaran satu rumah sangat cepat terjadi karena kerapatan bangunan permukiman dan jenis bahan bangunan yang digunakan didominasi kayu [8].

Menurut hasil pendataan oleh pemerintah Kota Banjarmasin. Persebaran permukiman kumuh Kelurahan Belitung Selatan terdapat di 10 RT. Yang termasuk dalam kategori kumuh ringan sebanyak 9 Rukun Tangga (RT 4,8,9,10,11,12,13,14,15) dan Kumuh Sedang 1 Rukun Tangga (RT 6), dengan luas permukiman kumuh pada 10 RT sebesar 6,04 Ha [9]. Kawasan kumuh terdiri sebanyak rumah 480 Unit dengan persebaran jumlah penduduk 1.920 jiwa pada kawasan permukiman kumuh Kelurahan Belitung Selatan [10]. Kelurahan Belitung Selatan termasuk dalam kawasan permukiman kumuh perkotaan dengan keadaan bangunan yang padat [11]. Kondisi jaringan jalan terbagi atas 2 jenis jaringan akses yaitu dengan jalan cor serta kondisi perkerasan kurang baik dan jalan titian kayu yang digunakan bagi warga bantaran sepanjang sungai dan kawasan rawa [12]. Kondisi sanitasi lingkungan pada kawasan kumuh yang berada di bantaran sungai masih menggunakan jamban apung dan fasilitas MCK komunal yang kondisinya kurang bagus [13]. Sistem persampahan di Kelurahan Belitung Selatan masih menggunakan sistem menumpuk dan membakar sampah secara individu di masing-masing RT [14].

Dari penjelasan tersebut diketahui garis besar kondisi karakteristik dan permasalahan kawasan permukiman kumuh di Kelurahan Belitung Selatan. Selanjutnya dilakukan analisis terhadap faktor penyebab kumuh di kawasan permukiman kumuh di Kelurahan Belitung Selatan untuk mengetahui besaran nilai bobot faktor-faktor dan variabel penyebab kumuh, 
sehingga diperoleh tingkatan faktor prioritas penyebab kumuh di kawasan permukiman kumuh Kelurahan Belitung Selatan Kota Banjarmasin.

\section{METODE PENELITIAN}

\section{A. Metode Pengumpulan Data}

Dalam penelitian ini menggunakan metode pengumpulan data primer dan sekunder. Pengumpulan data dengan survey primer melalui wawancara, kuesioner dan observasi. Kuesioner terkait identifikasi karakteristik kawasan permukiman kumuh yang disebarkan ke masyarakat di permukiman kumuh Kelurahan Belitung Selatan. Wawancara dilakukan melalui analisa stakeholder pada stakeholder yang terkait, yaitu Bappeda Kota Banjarmasin, Dinas Cipta Karya dan Perumahan Kota Banjarmasin, Dinas PU dan Bina Marga Kota Banjarmasin, Dinas Tata Ruang \& Tata Bangunan Kota Banjarmasin, Kelurahan Belitung Seelatan, Pakar Bidang Perumahan dan Permukiman serta Tokoh Masyarakat Kelurahan Belitung Selatan.

Data sekunder digunakan sebagai pelengkap data-data primer yang telah didapatkan. Metode pengumpulan data sekunder dalam penelitian ini adalah studi pustaka dan survei instansi. Kebutuhan data tersebut tersedia dalam dokumen rencana serta informasi mengenali kawasan permukiman kumuh di Kelurahan Belitung Selatan.

\section{B. Metode Analisis}

Metode analisis dalam penelitian ini untuk penentuan faktor prioritas penyebab kumuh memiliki tahapan disetiap sasarannya. Setiap sasaran penelitian menggunakan alat analisis yang berbeda. Untuk keseluruhan analisis, alat analisis yang digunakan antara lain adalah analisis deskriptif kualitatif bertujuan mengidentifikasi karakteristiik kawasan permukiman kumuh di Kelurahan Belitung Selatan.

Analisa stakeholder dilakukan untuk mengumpulkan dan menganalisis informasi secara kualitatif untuk menentukan kepentingan siapa yang harus diperhitungkan ketika mengembangkan atau menerapkan suatu kebijakan yang dilakukan oleh stakeholder terkait penentuan faktor prioritas penyebab kumuh. Analisis AHP (Analythical Hierarchy Process) digunakan dalam menentukan besaran masing-masing faktor penyebab kumuh yang dilakukan oleh para stakeholder dalam menentukan faktor prioritas penyebab kumuh di kawasan permukiman kumuh Kelurahan Belitung Selatan Kota Banjarmasin.

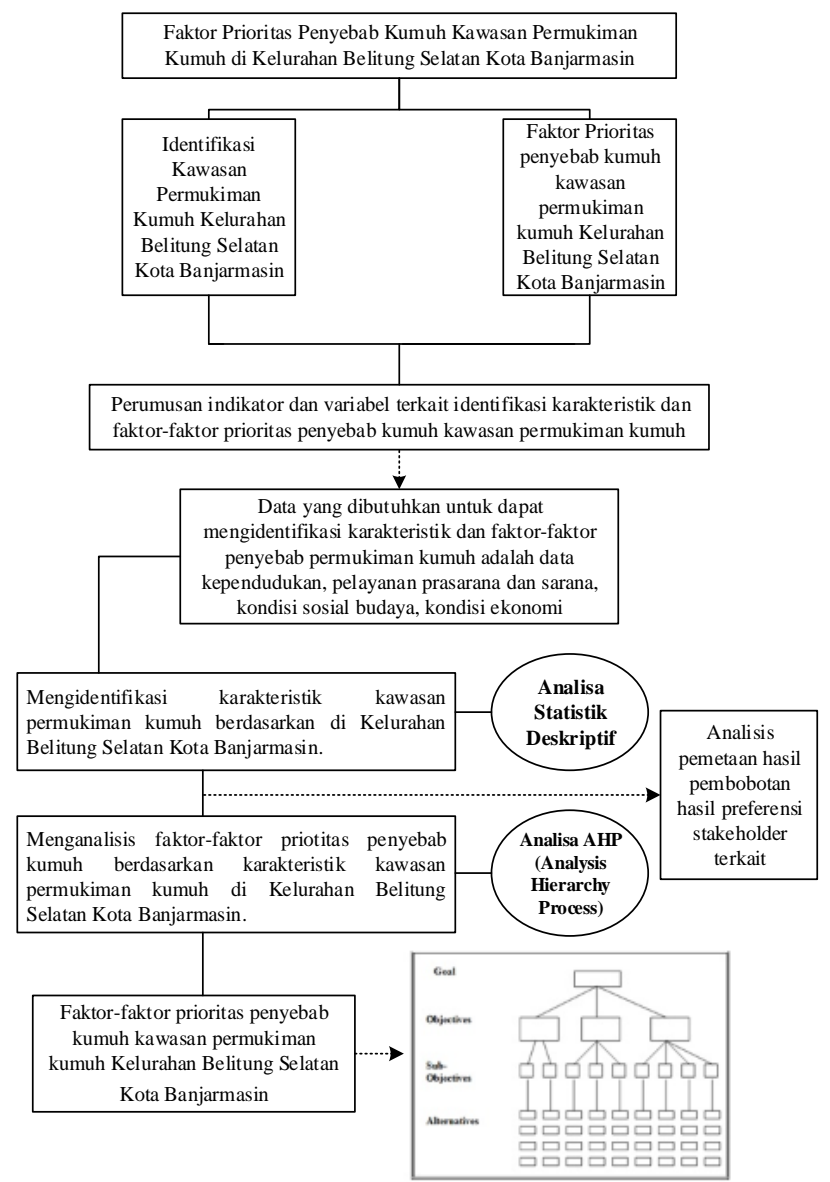

Gambar 1. Alur Analisa untuk faktor prioritas penyebab kumuh permukiman kumuh Kelurahan Belitung Selaatan Kota Banjarmasin Sumber : Hasil Analisa, 2016

\section{HASIL DAN PEMBAHASAN}

\section{A. Identifikasi Karakteristik Kawasan Permukiman Kumuh}

Hasil identifikasi karakteristik permukiman kumuh diperoleh melalui penyebaran kuesioner yang di kawasan penelitian. Berikut ini beberapa poin karakteristik kawasan permukiman kumuh Kelurahan Belitung Selatan Kota Banjarmasin :

1) Kondisi Fisik Bangunan

Kualitas bangunan dinilai dari hasil pembobotan yang ditinjau berdasarkan karakteristik bangunan :

a) Bangunan mengalami kebocoran yang diakibatkan oleh kerusakan seperti berlubang karena faktor umur material seng yang sudah cukup lama dan mengalami korosi diakibatkan air hujan.

b) Bangunan papan kayu dengan kondisi pada beberapa rumah mengalami kerusakan diakibatkan pelapukan usia kayu disebabkan umur material yang sudah cukup lama.

c) Material lantai berbahan ubin kayu dengan lapisan karpet plastik. Kondisi pada beberapa lantai rumah masih dalam kondisi baik, dilihat dari masih kuatnya kayu yang digunakan.

Mayoritas masyarakat Kelurahan Belitung Selatan telah memiliki legalitas status tanah berupa hak milik serta hak sewa, dilihat dari $66,22 \%$ responden yang memiliki status tersebut. Hal itu dilihat dari jangka waktu masyarakat 
Kelurahan Belitung Selatan telah bertempat tinggal dilokasi tersebut, dimana rata-rata telah bertempat tinggal 16 - 20 tahun hingga $>20$ tahun. Hal itu dilihat dari presentase responden sebesar $85.53 \%$.
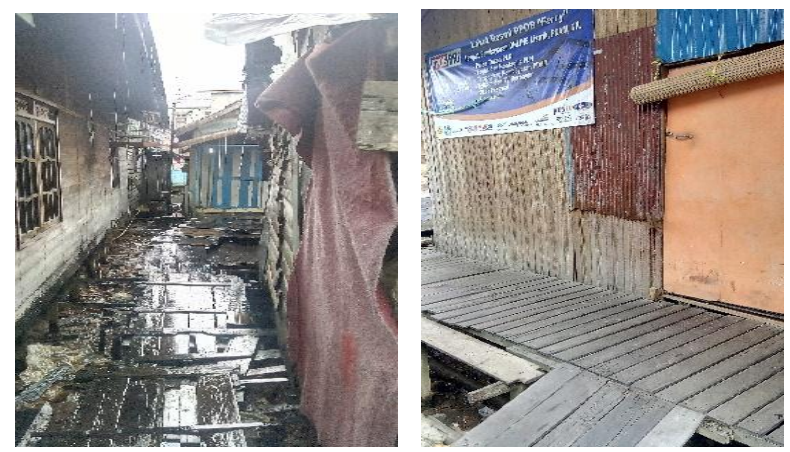

Gambar 2. Kondisi Fisik Bangunan Permukiman Kumuh Kelurahan Belitung Selatan Kota Banjarmasin.

Sumber : Dokumentasi Pribadi, 2016

Kawasan permukiman kumuh Kelurahan Belitung Selatan memiliki tingkat kepadatan bangunan yang merata pada seluruh kawasan permukiman kumuh. Tingkat kepadatan tertinggi terdapat di RT.06 sebesar $10.26 \mathrm{Unit} / \mathrm{Ha}$, sedangkan tingkat kepadatan rata-rata bangunan di perkampungan Kelurahan Belitung Selatan sebesar 72.84 unit/Ha. Angka tersebut memiliki arti bahwa secara umum, Kelurahan Belitung Selatan memiliki tingkat kepadatan bangunan yang sedang. Meningkatnya kebutuhan penduduk terhadap kepemilikan rumah tidak sejalan dengan ketersediaan lahan yang diperuntukkan bagi permukiman masyarakat. Hal itu ditambah pula dengan semakin mahalnya harga lahan di wilayah perkotaan Kota Banjarmasin.

2) Kondisi Sarana dan Prasarana

Hasil analisa variabel dan karakteristik kawasan permukiman kumuh di Kelurahan Belitung Selatan :

a) Sarana Fasilitas Pendidikan

Berdasarkan jumlah fasilitas pendidikan yang tersedia hanya TK \& SD, sehingga untuk melanjutkan ke tingkat pendidikan selanjutnya penduduk permukiman kumuh Kelurahan Belitung Selatan harus melanjutkan ke fasilitas pendidikan di Kecamatan lainnya.

b) Sarana Fasilitas Peribadatan

Fasilitas peribadatan yang tersebar di permukiman kumuh Kelurahan Belitung Selatan berupa 2 musholla dan 1 masjid. Untuk kebutuhan berdasarkan penduduk masih kurang mencukupi tetapi dari kondisi fisik fasilitas dapat dinilai layak.

c) Sarana Fasilitas Kesehatan

Fasilitas kesehatan yang tersebar di permukiman kumuh Kelurahan Belitung Selatan berupa posyandu yang terletak di setiap RT. Untuk kebutuhan berdasarkan penduduk masih kurang mencukupi, tetapi dari kondisi fisik fasilitas dapat dinilai kurang layak.

d) Sarana Fasilitas Perdagangan \& Jasa

Berdasarkan hasil kusioner dan observasi di Kelurahan Belitung Selatan terdapat karakteristik sarana fasilitas peribadatan 2 musholla dan 1 masjid. Untuk sarana fasilitas perdagangan jasa terdapat 1 pasar dan sarana fasilitas kesehatan 2 posyandu, serta sarana fasilitas pendidikan berupa SD dan TK.

e) Prasarana Jaringan Drainase

Di keseluruhan kawasan permukiman kumuh Kelurahan Belitung Selatan tidak memiliki jaringan drainase yang disebabkan oleh minimnya sempadan jalan yang tersedia serta jarak antar bangunan yang sangat padat sehingga tidak dapat dibangun selokan atau gorong-gorong sebagai drainase lingkungan permukiman.
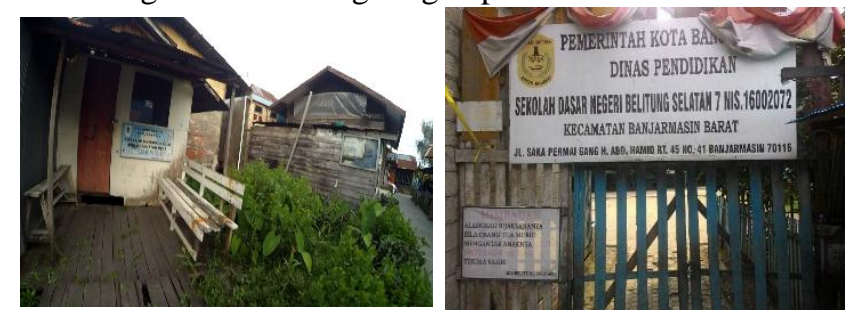

Gambar 3. Kondisi Sarana dan Prasarana Permukiman Kumuh Kelurahan Belitung Selatan Kota Banjarmasin.

Sumber : Dokumentasi Pribadi, 2016

Hasil analisa variabel dan karakteristik kawasan permukiman kumuh di Kelurahan Belitung Selatan dapat dijelaskan sebagai berikut :

a) Sistem drainase dan pengendalian banjir tidak tersedia di kawasan permukiman kumuh Kelurahan Belitung Selatan, sehingga dinilai sangat kurang dalam kualitas serta penyediaan sistem drainase.

b) Kualitas jaringan air di kawasan permukiman kumuh Kelurahan Belitung Selatan sudah baik. Hal ini dilihat dari telah terlayaninya jaringan air melalui PDAM yang mencapai $81.92 \%$, sehingga karakteristik kaawasan kumuh terkait ketersediaan serta kualitas jaringan air bersih telah cukup terpenuhi.

c) Kualitas sistem pembuangan air limbah sudah cukup baik. Ini dinilai dari penggunaan WC di setiap rumah yang mencapai $85.54 \%$ serta penggunaan septic tank sebesar $63.85 \%$ di kawasan permukiman kumuh Kelurahan Belitung Selatan.

\section{3) Kondisi Sosial dan Ekonomi Masyarakat}

Pendapatan masyarakat di permukiman kumuh Kelurahan Belitung Selatan masih kurang dari UMK Kota Banjarmasin sebesar Rp 2.150.000,-. Dilihat dari total responden keseluruhan sebanyak 63 responden atau 75,90\% memiliki tingkat pendapatan masih dibawah UMK Kota Banjarmasin, artinya hanya sebesar 20 responden atau $24,09 \%$ yang memiliki tingkat pendapatan diatas UMK yang telah ditetapkan. Berdasarkan presentase tersebut terlihat masih tingginya tingkat masyarakat pra sejahtera di kawasan permukiman kumuh Kelurahan Belitung Selatan, yang disebabkan oleh $75.90 \%$ masih berpendapatan dibawah UMK. Dari kondisi tersebut diperlukan penanganan terhadap peningkatan pendapatan masyarakat yang masih kurang agar dapat menurunkan tingkat keluarga pra sejahtera. Untuk tingkat pendidikan terlihat masih banyak masyarakat yang berpendidikan rendah. Hal tersebut dinilai dari $60.24 \%$ responden atau masyarakat di permukiman kumuh Kelurahan Belitung Selatan yang memiliki status jenjang pendidikan 
hanya tamatan SD sampai SMP. Ini juga disebabkan masih kurangnya fasilitas pendidikan serta pelayanan fasilitas pendidikan yang kurang baik.

Kawasan permukiman kumuh Kelurahan Belitung Selatan memiliki rata-rata penduduk $192 \mathrm{jiwa} / \mathrm{Ha}$ dengan kepadatan penduduk dalam kategori sedang, dan laju pertumbuhan penduduk setiap tahunnya $0.01 \%$. Arus migrasi di permukiman kumuh Kelurahan Belitung Selatan masih tergolong rendah. Hal itu dapat dilihat jangka waktu masyarakat Kelurahan Belitung Selatan telah bertempat tinggal dilokasi tersebut, dimana rata-rata $16-20$ tahun hingga $>20$ tahun.

\section{4) Kondisi Pengendalian Hukum}

Masih adanya beberapa pelanggaran seperti beberapa bangunan rumah yang berdiri pada daerah sempadan sungai, khususnya pada area RT (6,8,9 dan 11). Masyarakat permukiman kumuh Kelurahan Belitung Selatan masih memiliki pengetahuan dan kesadaran hukum yang kurang. Hal ini dapat dilihat dari masih adanya beberapa pelanggaran seperti beberapa bangunan rumah yang berdiri pada daerah sempadan sungai, sistem persampahan yang masih belum terintegrasi karena masih kurangnya kepekaan masyarakat serta tata cara pembuangan air limbah secara langsung ke lingkungan masyarakat di kawasan permukiman kumuh Kelurahan Belitung Selatan.

\section{B. Faktor Prioritas Penyebab Kumuh Kawasan Permukiman Kumuh}

Dalam menentukan faktor prioritas penyebab kumuh, sebelumnya perlu dilakukan analisa stakeholder terlebih dahulu untuk menentukan stakeholder yang menentukan tingkatan prioritas faktor berdasarkan tingkat kepentingan dan pengaruh dalam faktor penyebab kumuh. Berdasarkan hasil analisa stakeholder dari komponen pemerintah, akademisi/pakar serta perwakilan masyarakat yang bertempat tinggal di permukiman kumuh. Analisis ini menggunakan software expert choice dengan sistem pembobotan pada masing-masing faktor serta variabel penyebab kumuh.
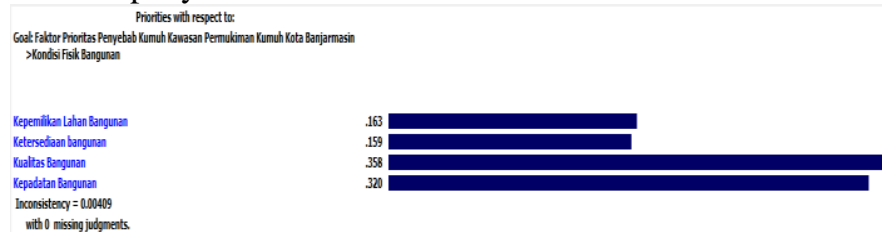

Gambar 4. Nilai Bobot Analysis Hierarchy Process Faktor Prioritas Penyebab Kumuh Berdasarkan Combine Stakeholder.

Sumber : Hasil Ekspert Choice, 2016

Tabel 1

Tingkatan Bobot Permukiman Kumuh di Kelurahan Belitung Selatan Kota Banjarmasin berdasarkan Kombinasi Seluruh Stakeholder.

\begin{tabular}{clcc}
\hline \hline No. & \multicolumn{1}{c}{ Indikator } & $\begin{array}{c}\text { Bobot } \\
\text { Indikator }\end{array}$ & $\begin{array}{c}\text { Prioritas } \\
\text { Penyebab } \\
\text { Kumuh }\end{array}$ \\
\hline 1. & $\begin{array}{l}\text { Kondisi Fisik Bangunan } \\
\text { Kondisi Sosial dan Ekonomi } \\
\text { Masyarakat }\end{array}$ & 0,365 & I \\
3. & $\begin{array}{l}\text { Kondisi Sarana dan Prasarana } \\
\text { Pengendalian Hukum }\end{array}$ & 0,204 & II \\
$\quad \begin{array}{ll}\text { Jumlah Bobot } \\
\text { Sumber }: \text { Hasil Ekspert Choice, 2016 }\end{array}$ & 0,161 & IV \\
\hline \hline
\end{tabular}

Berdasarkan hasil analisa AHP diatas, diketahui bahwa indikator penyebab kumuh pada kawasan permukiman kumuh yang memiliki prioritas paling tinggi berdasarkan preferensi keseluruhan stakeholder adalah indikator kondisi fisik bangunan dengan bobot 0,365 ; kemudian kondisi sosial dan ekonomi masyarakat dengan bobot 0,270 ; kondisi sarana dan prasarana dengan bobot 0,204 ; dan pengendalian hukum dengan bobot 0,161 .

Hasil analisa para stakeholder dinilai melalui pembobotan secara sama dalam faktor prioritas penyebab kumuh, dimana penilaian tersebut diperoleh dari indikator dan variabel masing faktor penyebab. Selanjutnya dilakukan pembobotan yang berorientasi pada indikator variabel yang mempengaruhi. Setelah diketahui hasil pembobotan atribut indikator untuk mengetahui seberapa besar prioritas yang dimiliki atribut indikator dalam mencapai tujuan. Hasil pembobotan antar variabel disajikan dalam bentuk tabel berdasarkan hasil penghitungan. Nilai Bobot Analytical Hierarchy Process Keseluruhan

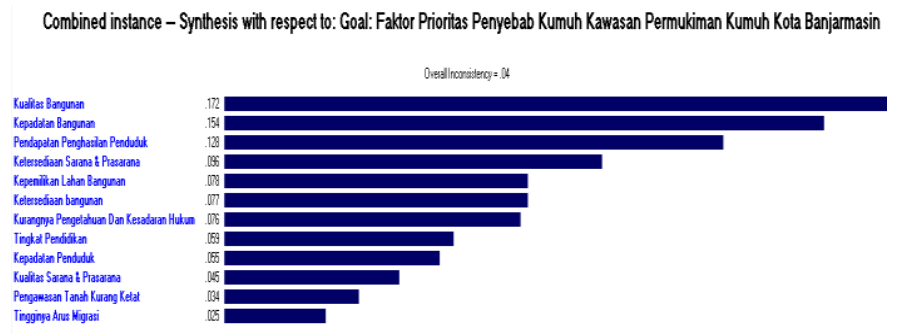

Gambar 5. Variabel Penyebab Kumuh Berdasarkan Combine Stakeholder hasil pembobotan melalui software expert choice.

Sumber: Hasil Ekspert Choice, 2016

Tabel 2

Tingkatan Bobot Keseluruhan Variabel Penyebab Kumuh Berdasarkan Kombinasi Seluruh Stakeholder.

\begin{tabular}{clc}
\hline \hline \multirow{2}{*}{ No } & \multicolumn{1}{c}{ Variabel } & $\begin{array}{c}\text { Presentase Nilai } \\
\text { Bobot }\end{array}$ \\
\hline 1. & Kualitas Bangunan & $17.2 \%$ \\
2. & Kepadatan Bangunan & $15.4 \%$ \\
3. & Pendapatan Penghasilan Penduduk & $12.8 \%$ \\
4. & Ketersediaan Sarana \& Prasarana & $9.6 \%$ \\
5. & Kepemilikan Lahan Bangunan & $7.8 \%$ \\
6. & Ketersediaan Bangunan & $7.7 \%$ \\
7. & Tingkat Pengetahuan Dan Kesadaran & $7.6 \%$ \\
& Hukum & \\
8. & Tingkat Pendidikan & $5.9 \%$ \\
9. & Kepadatan Penduduk & $5.5 \%$ \\
10. & Kualitas Sarana \& Prasarana & $4.5 \%$ \\
11. & Pengawasan Tanah Kurang Ketat & $3.4 \%$ \\
12. & Tingkat Arus Migrasi & $2.5 \%$ \\
\hline \hline Sumber $:$ Hasil Ekspert Choice, 2016
\end{tabular}

Dari perhitungan pembobotan melalui analisa AHP (Analytic Hierarchy Process) bahwa variabel yang memiliki nilai bobot tertinggi hingga terendah variabel prioritas penyebab kumuh permukiman kumuh di Kelurahan Belitung Selatan. Variabel tertinggi penyebab kumuh yaitu kualitas bangunan sebesar $17.2 \%$, sedangkan untuk variabel terendah penyebab kumuh adalah tingkat arus migrasi sebesar $2.5 \%$.

1) Kualitas Bangunan (Nilai bobot 0,172) 
Parameter penilaian kualitas bangunan di kawasan permukiman kumuh yang diukur berdasarkan dengan jenis material bangunan yang digunakan pada bagian lantai, dinding, atap serta ketersediaan sistem pencahayaan dan sirkulasi udara yang baik pada setiap bangunan. Penilaian tersebut memberikan layak atau tidak layaknya bangunan yang masyarakat huni.

2) Kepadatan Bangunan (Nilai Bobot 0,154)

Pengukuran variabel yang dilakukan melihat jarak antar banggunan serta tingkat pertumbuhan bangunan pada setiap kawasan permukiman kumuh, dimana semakin tinggi pertumbuhan bangunan maka semakin padat suatu kawasan.

3) Pendapatan Penghasilan Penduduk (Nilai Bobot 0,128) Variabel ini diukur melalui tingkat pendapatan penduduk per kapita dengan dibandingkan UMR skala kota serta diperjelas berdasarkan jenis pekerjaan yang masayarakat yang akan menggambarkan dari segi kemampuan ekonomi masyarakat di kawasan permukiman kumuh.

4) Ketersediaan Sarana \& Prasarana (Nilai Bobot 0,096) Pengukuran parameter dilakukan melalui ketersediaan sarana dan prasarana dalam memenuhi kebutuhan masyarakat terhadap fasilitas-fasilitas seperti pendidikan, kesehatan, peribadatan, perdagangan jasa, rekreasi dan olahraga.

5) Kepemilikan Lahan Bangunan (Nilai 0,078)

Variabel ini dilihat dari status kempemilikan lahan pada bangunan yang telah didirikan, dengan mengukur seberapa besar kesesuaian status lahan dengan peruntukan pemanfaatan ruang sesuai dengan rencana di kawasan permukiman kumuh.

6) Ketersediaan Bangunan (Nilai Bobot 0,077)

Ketersediaan bangunan dinilai berdasarkan besaran ketersediaan lahan terhadap pemanfataan lahan yang diperuntukkan sebagai kawasan permukiman dengan mengukur seberapa besar kebutuhan masyarakat terhadap lahan untuk kawasan permukiman.

7) Tingkat pengetahuan \& keasadaran hukum (Nilai Bobot $0,076)$

Kurangnya pengetahuan dan kesadaran hukum menjadi salah satu penyebab munculnya permukiman kumuh dalam faktor pengendalian hukum, dikarenakan kurangnya sosialisasi perundang-undangan dan rencana tata ruang sebagai pengetahuan masyarakat terhadap penataan ruang serta kesadaran peran masyarakat dalam perencanaan khususnya permukiman.

8) Tingkat Pendidikan (Nilai Bobot 0,059)

Tingkat pendidikan memiliki pengaruh terhadap pengetahuan dan sikap masyarakat di lingkungan permukiman. Rendahnya tingkat pendidikan akan berdampak pada pola pikir dan kegiatan antar masyarakat menurunkan kepedulian terhadap lingkungan sekitar, serta berpengaruh pada kondisi ekonomi yang kurang dikarenakan standar pendidikan memiliki pengaruh dalam jenis pekerjaan yang dilakoni oleh masyarakat.

9) Kepadatan Penduduk (Nilai Bobot 0,055)

Pembobotan dilakukan berdasarkan tingkat pertumbuhan penduduk serta besaran tingkat kepadatan penduduk per luas wilayah kawasan permukiman kumuh.

10) Kualitas Sarana \& Prasana (Nilai Bobot 0,045 )
Kualitas sarana dan prasarana dinilai dari fisik bangunan fasilitas serta kualitas pelayanan publik sarana dan prasarana yang masih kurang baik terhadap masyarakat di kawasan permukiman kumuh.

11) Pengawasan Tanah Kurang Ketat (Nilai Bobot 0,034) Pengawasan tanah yang kurang ketat menimbulkan banyak pertumbuhan bangunan yang kurang sesuai dengan pemanfaatan ruang, serta masih belum adanya penegakan hukum terhadap penggunaan lahan yang masih belum sesuai dengan peruntukan awal dalam rencana kawasan khususnya di kawasan permukiman kumuh.

12) Tingkat Arus Migrasi (Nilai Bobot 0,025)

Besaran tingkat perpindahan penduduk dari daerah lain menuju kawasan permukiman kumuh, disebabkan oleh keterikatan masyarakat antara tempat tinggal dengan aktivitas ekonomi atau lokasi pekerjaan sehingga menimbulkan perpindahan penduduk

\section{KESIMPULAN}

Berdasarkan hasil identifikasi karakteristik kawasan permukiman kumuh di Kelurahan Belitung Selatan Kota Banjarmasin. Hampir keseluruhan bangunan berdiri berada pada lahan berkarakteristik gambut yang memiliki kadar air cukup besar.

1) Kualitas bangunan yang kurang baik dengan rentang waktu massa bangunan lebih dari 20 tahun, dengan satatus kepemilikan berupa hak milik dan girik.

2) Kepadatan bangunan tinggi dengan rata-rata material bangunan kayu serta jaringan drainase yang belum tersedia.

3) Masyarakat kawasan permukiman kumuh Kelurahan Belitung Selatan memiliki tingkat pendapatan cukup rendah sehingga masih di bawah UMR Kota Banjarmasin.

4) Dari segi pelayanan fasilitas sarana dan prasarana masih sangat buruk, diakibatkan kualitas bangunan serta sistem pelayanan sarana dan prasarana yang masih kurang.

5) Masih belum terdapatnya program mitigasi bencana terkait evakuasi, dilihat dari tingginya angka bencana kebakaran di Kota Banjarmasin.

Terdapat 4 indikator penyebab prioritas penyebab kumuh. Dari analisa didapat faktor prioritas penyebab kumuh sebagai berikut berdasarkan bobot nilai terbesar yaitu (1) Kondisi Fisik Bangunan (2) Kondisi Sosial Ekonomi Masyarakat (3) Kondisi Sarana dan Prasarana (4) Pengendalian Hukum. Dari perhitungan pembobotan melalui analisa AHP (Analytic Hierarchy Process), variabel yang memiliki nilai bobot tertinggi hingga terendah variabel prioritas penyebab kumuh permukiman kumuh di Kelurahan Belitung Selatan adalah sebagai berikut : (1) Kualitas Bangunan (2) Kepadatan Bangunan. (3) Pendapatan Penghasilan Penduduk. (4) Ketersediaan Sarana \& Prasarana. (5) Kepemilikan Lahan Bangunan. (6) Ketersediaan Bangunan. (7) Tingkat pengetahuan \& kesadaran hukum. (8) Tingkat Pendidikan. (9) Kepadatan Penduduk. (10) Kualitas Sarana \& Prasana. (11) Pengawasan Tanah Kurang Ketat. (12) Tingkat Arus Migrasi.

Variabel yang memiliki prioritas utama yaitu kualitas bangunan dengan nilai bobot sebesar 17.2\%. Hal itu disebabkan oleh besarnya pengaruh kualitas material bangunan serta umur 
bangunan yang cukup lama di kawasan permukiman kumuh Kelurahan Belitung Selatan, sedangkan variabel paling rendah menurut hasil analisis adalah tingkat arus migrasi dikarenakan masih minimnya arus migrasi dari di kawasan permukiman kumuh Kelurahan Belitung Selatan. Hal tersebut diperkuat oleh lama tinggalnya masyarakat yang lebih dari $>15$ Tahun, serta minimnya ketersediaan lahan terhadap bangunan baru bagi masyarakat yang ingin melakukan migrasi ke Kelurahan Belitung Selatan Kota Banjarmasin.

\section{DAFTAR PUSTAKA}

[1] Adisasmita, H. Rahardjo. 2005. Pembangunan Ekonomi Perkotaan. Yogyakarta: Graha Ilmu.

[2] Budiharjo, Eko. 2009. Perumahan dan Permukiman di Indonesia. Semarang: P.T. Alumni

[3] Komarudin. 1999. Pembangunan Perkotaan Berwawasan Lingkungan. Jakarta: Dirjen Cipta Karya Departemen Pekerjaan Umum

[4] Sinulingga, Budi D. 1999. Pembangunan Kota: Tinjauan Regional dan Lokal. Jakarta: Pustaka Sinar Harapan. Adisasmita. H.R. 2005. Dasardasar Ekonomi Wilayah. Jakarta: Graha Ilmu.

[5] Yunus, Hadi Sabari. 2000. Struktur Tata Ruang Kota. Yogyakarta: Pustaka Pelajar.

[6] Pardino. (2005). Modul Pelatihan Pemberdayaan Masyarakat Bidang Pekerjaan Umum. Departemen Pekerjaan Umum.

[7] Masyhuri, M. Zainuddin. 2008. Metodologi Penelitian Pendekatan Praktis dan Aplikatif. PT. Refika Aditama: Bandung.

[8] Undang-Undang Nomor 1 Tahun 2011 tentang Perumahan dan Kawasan Permukiman.

[9] Parwata, I Wayan. 2004. Dinamika Permukiman Perdesaan Pada Masyarakat Bali. Denpasar: Direktorat Jenderal Pendidikan Tinggi

[10] SK Walikota Banjarmasin No. 460 Tahun 2015.

[11] Pedoman Identifikasi Kawasan Permukiman Kumuh Daerah Penyangga Kota Metropolitan.

[12] Rencana Pengembangan Kawasan Permukiman Prioritas (RPKPP) Kota Banjarmasin Tahun 2011

[13] Penyusunan Identifikasi Kawasan Kumuh Kota Banjarmasin Tahun 2014.

[14] Rencana Pembanguanan dan Pengembangan Perumahan dan Kawasan Permukiman (RP3KP) Kota Banjarmasin Tahun 2012. 